\title{
Suppressive activity of tiotropium bromide on matrix metalloproteinase production from lung fibroblasts in vitro
}

\author{
Kazuhito Asano' \\ Yusuke Shikama ${ }^{2}$ \\ Yasuhiro Shibuya ${ }^{2}$ \\ Hiroaki Nakajima ${ }^{2}$ \\ Ken-ichi Kanai ${ }^{3}$ \\ Naohiro Yamada ${ }^{3}$ \\ Harumi Suzaki ${ }^{3}$ \\ 'Division of Physiology, School \\ of Nursing and Rehabilitation \\ Sciences; ${ }^{2}$ Respiratory Disease \\ Center, Showa University Northern \\ Yokohama Hospital, Yokohama, Japan; \\ ${ }^{3}$ Department of Otolaryngology, \\ School of Medicine, Showa \\ University, Tokyo, Japan
}

\begin{abstract}
Background: Chronic obstructive pulmonary disease (COPD) is characterized by airway remodeling with an accumulation of inflammatory cells. There is also increasing evidence that metalloproteinases (MMPs) may contribute to the pathogenesis of COPD, but the influence of agents that used for the treatment of COPD is not well understood.

Objective: We evaluated whether tiotropium bromide hydrate (TBH), a $\mathrm{M}_{3}$ muscarinic receptor antagonist, could inhibit MMP production from lung fibroblasts (LFs) in response to tumor necrosis factor (TNF)- $\alpha$ stimulation.

Methods: LFs were established from normal lung tissues taken from patients with lung tumors. LFs $\left(5 \times 10^{5}\right.$ cells $\left./ \mathrm{ml}\right)$ were stimulated with TNF- $\alpha$ in the presence of various concentrations of TBH. After $24 \mathrm{~h}$, culture supernatants were obtained and assayed for the levels of MMPs and tissue inhibitor of metalloproteinases (TIMPs) by ELISA. The influence of TBH on mRNA expression of MMPs and TIMPs in $4 \mathrm{~h}$-cultured cells was also examined by real-time RT-PCR. Furthermore, nuclear factor- $\mathrm{KB}(\mathrm{NF}-\mathrm{\kappa B})$ and activator protein-1 (AP-1) in LFs treated with TBH for $4 \mathrm{~h}$ was examined by ELISA.

Results: TBH at more than $15 \mathrm{pg} / \mathrm{ml}$ inhibited the production of MMP-2 from LFs after TNF- $\alpha$ stimulation, whereas TIMP-1 and TIMP-2 production was scarcely affected by TBH through the suppression of both mRNA expression and transcription factor, NF- $\kappa \mathrm{B}$, activation in LFs induced by TNF- $\alpha$ stimulation.

Conclusion: These results suggest that the attenuating effect of TBH on MMP-2 production from LFs induced by inflammatory stimulation may be additional benef icial therapeutic effects not directly relating to its bronchodilatory effects.
\end{abstract}

Keywords: tiotropium, lung fibroblasts, matrix metalloproteinases, suppression, in vitro

\section{Introduction}

Chronic obstructive pulmonary disease (COPD) is well accepted to be attributed to long-term exposure to toxic gases and particles, most often related to cigarette smoking. Histological observations of lung tissues of patients with COPD revealed the presence of the airway remodeling with the inflammatory responses (Hamid et al 2004; Hogg et al 2004; Jeffery 2004).

Matrix metalloproteinases (MMPs) are a large family of $\mathrm{Zn}^{2+}$ and $\mathrm{Ca}^{2+}$ dependent proteolytic enzymes, which are secreted by a wide variety of cells (eg, inflammatory cells, epithelial cells, and fibroblasts, etc) and essential for tissue remodeling, and have the ability to degrade various components of the extracellular matrix and basement membrane (Murphy et al 1992; Herouy et al 2001). They are accepted to be implicated in normal physiological tissue remodeling, inflammation, and tumor spread. It is widely recognized that many MMPs are expressed in the human lungs, and there is compelling evidence linking MMPs to small airway tissue remodeling, which is the most important histological finding of COPD (Ohnishi et al 1998; Demedts et al 2005; 
Lagente et al 2005; Baraldo et al 2007). It is also reported that levels of MMPs in both lung tissues and bronchoalveolar lavage fluids, including sputum, increase as lung function worsens and the degree of airway remodeling increases (Cataldo et al 2000; Kang et al 2003; Babusyte et al 2007). Although these reports may suggest that MMPs seem to be good candidates for possible therapeutic targets in the COPD treatment, there is little evidence showing the influence of the agents that used for COPD treatment on MMPs.

Tiotropium bromide hydrate $(\mathrm{TBH})$, the first choice agent in the treatment of COPD (Rodrigo et al 2007), is a once-daily inhaled anticholinergic bronchodilator, which binds to muscarinic receptor subtypes $\left(M_{1}, M_{2}\right.$, and $\left.M_{3}\right)$, and exhibits a long duration of action due to prolonged $\mathrm{M}_{3}$ receptor antagonism (Disse 2001). There is much evidence that long-term administration of TBH improves the clinical status of COPD patients (Casaburi et al 2002; Vincken et al 2002; Dusser et al 2006). Although experimental evidence showed that $\mathrm{TBH}$ could protect airway smooth muscle remodeling, which is observed in COPD and asthma (Hamid et al 2004; Gosens et al 2005), the influence of TBH on the production of MMP, which is the most important enzymes for remodeling, is not fully understood. In the present study, therefore, we examined the influence of TBH on MMPs production from lung fibroblasts in vitro.

\section{Materials and methods}

Agent

TBH was extracted from inhalable powders for therapeutic use that contained $22.5 \mu \mathrm{g} \mathrm{TBH}$ and $32.5 \mu \mathrm{g}$ lactose. The powder was dissolved in RPMI-1640 medium supplemented with $10 \%$ fetal bovine serum (RPMI-FCS) in a volume of $5.0 \mathrm{ml}$. This solution was then sterilized by passing through $0.2 \mu \mathrm{m}$ filters and stored at $4{ }^{\circ} \mathrm{C}$ as a stock solution until used. All dilutions used in this study were prepared from this stock solution by diluting with RPMI-FCS. To use the medium for control, $32.5 \mu \mathrm{g}$ lactose (Sigma Chemicals, Co., Ltd, St Louis, MO, USA) was dissolved in $5.0 \mathrm{ml}$ RPMI-FCS, sterilized, diluted with RPMI-FCS in a similar manner. Recombinant TNF- $\alpha$ (preservative-free) was purchased from Chemicon International, Inc. (Temecula, CA, USA) and diluted with RPMI-FCS to give a concentration of $50.0 \mathrm{ng} / \mathrm{ml}$.

\section{Cell source and induction of fibroblasts}

Tissue samples from patients without lung fibrosis or COPD were obtained from healthy tissue area during pneumonectomy for tumor resection from a tumor-free area. All donors ( 3 female, 43-71 years; 2 male, 41 and 71 years) were given a written informed consent, which was approved by the Ethics Committee of Showa University. The diced tissue specimens (approximately $1 \mathrm{~mm}^{2}$ ) were plated at a density of 10 pieces in $100 \mathrm{~mm}$ tissue culture dishes and covered with a cover slip adhered to the dishes. The dishes were then placed in a humidified atmosphere containing $5 \% \mathrm{CO}_{2}$ at $37^{\circ} \mathrm{C}$. When a monolayer of fibroblast-like cells was found to be confluent, the explanted tissues were removed. The cells were then trypsinized, and replated at a concentration of $5 \times 10^{5}$ cells $/ \mathrm{ml}$ into $100 \mathrm{~mm}$ tissue culture dishes with a final volume of $10.0 \mathrm{ml}$. Subsequently, the cells were split 1:2 at confluence and passaged (Suzaki et al 2003). The cells were characterized with antibodies against vimentine, cytokeratin and fibronectine, using fluorescent microscopy (Model No. IX 70, OLYMPAS Co., Ltd, Tokyo, Japan; Suzaki et al 2003), and the fibroblast purity was more than $99 \%$ and used as lung-derived fibroblasts (LFs). LFs at six to seven passages were used for the following experiments.

\section{Cell culture}

LFs were washed several times with RPMI-FCS, introduced into each well of 24-well culture plates in triplicate at a concentration of $5 \times 10^{5}$ cells $/ \mathrm{ml}$ in a volume of $1.0 \mathrm{ml}$. The cells were stimulated with $25.0 \mathrm{ng} / \mathrm{ml} \mathrm{TNF}-\alpha$ in the presence of various concentrations of TBH in a final volume of $2.0 \mathrm{ml}$. After $24 \mathrm{~h}$, the culture supernatants were removed, and stored at $-40{ }^{\circ} \mathrm{C}$ until used. In cases of examining transcription factor activation and mRNA expression, cells were cultured in a similar manner for $4 \mathrm{~h}$ and stored at $-80^{\circ} \mathrm{C}$ until used. In all cases, TBH was added to cell cultures $2 \mathrm{~h}$ before the stimulation with TNF- $\alpha$.

\section{Assay for MMP and TIMP}

MMP-2, MMP-9, TIMP-1, and TIMP-2 levels in culture supernatants were assayed using commercially available human MMP and TIMP ELISA test kits (Amersham Biosciences, Bucks, UK) according to the manufacturer's recommendation. The results are expressed as the mean $\mathrm{ng} / \mathrm{ml} \pm$ standard error (SE) of duplicate assays for five subjects. The minimum detectable levels of these ELISA kits were $0.37 \mathrm{ng} / \mathrm{ml}$ for MMP-2, $0.6 \mathrm{ng} / \mathrm{ml}$ for MMP-9, $40.0 \mathrm{ng} / \mathrm{ml}$ for TIMP-1, and $3.0 \mathrm{ng} / \mathrm{ml}$ for TIMP-2, respectively.

\section{Real-time polymerase chain reaction (PCR)}

mRNA was extracted from fibroblasts using $\mu$ MACS mRNA isolation kits (Milteny Biotec GmbH, Bergisch Gladbach, Germany) according to the manufacturer's instructions. 
The first-strand cDNA synthesis from $1.0 \mu \mathrm{g}$ mRNA was performed using the SuperScript Preamplif ication System for cDNA synthesis (GIBCO BRL, Gaithersburg, MD, USA). PCR was then carried out using a GeneAmp 5700 Sequence Detection System (Applied Biosystems, Foster City, CA, USA). PCR mixture consisted of $2.0 \mu \mathrm{l}$ of sample cDNA solution (10.0 ng/ $\mu \mathrm{l}$ ), $25.0 \mu \mathrm{l}$ of SYBR-Green Mastermix (Applied Biosystems), $0.3 \mu \mathrm{l}$ of both sense and antisense primers, and distilled water to give a final volume of $50 \mu \mathrm{l}$. The reaction was conducted as follows: $4 \mathrm{~min}$ at $95^{\circ} \mathrm{C}$, followed by 40 cycles of $15 \mathrm{sec}$ at $95^{\circ} \mathrm{C}$ and $60 \mathrm{sec}$ at $60{ }^{\circ} \mathrm{C}$. $\beta$-actin was amplified as an internal control. mRNA levels were calculated by using the comparative parameter threshold cycle $(\mathrm{Ct})$ and normalized to $\beta$-actin. Oligonucleotide sequences of the primers used were shown in Table 1.

\section{Assay for NF- $\kappa B$ and AP-I activities}

$\mathrm{NF}-\kappa \mathrm{B}$ activity was analyzed with commercially available ELISA test kits (Active Motif Co. Ltd., Carlsbad, CA, USA) that contained sufficient reagents and monoclonal antibodies against p50 and p65, according to the manufacturer's recommended procedure. In brief, nuclear extract $(5.0 \mu \mathrm{g}$ protein) from LFs was introduced into each well of 96-well microtiter plates pre-coated with oligonucleotide containing the NF- $\kappa \mathrm{B}$ consensus site (5'-GGGACTTTCC-3') in a volume of $20.0 \mu \mathrm{l}$, and incubated for $1 \mathrm{~h}$ at $25^{\circ} \mathrm{C}$. After washing three times, $100 \mu \mathrm{l}$ of monoclonal antibody against p50 or p65 was added to the appropriate wells, and incubated for a further $1 \mathrm{~h}$ at $25^{\circ} \mathrm{C}$. Anti-IgG HRP-conjugate in a volume of $100 \mu \mathrm{l}$ was then added and incubated $1 \mathrm{~h}$ at $25^{\circ} \mathrm{C}$. Absorbance at $450 \mathrm{~nm}$ was measured after the addition of tetramethylbenzine solution. AP-1 activity was also examined using a commercially available ELISA test kit (Active Motif, Co., Ltd), which contains sufficient reagents and monoclonal antibodies against Fra 2 and Jun B, according to the manufacturer's instructions. Using the manufacturer's data sheet, the amount of NF- $\mathrm{KB}$ and AP-1, bound to DNA can be measured by these two ELISA systems.

\section{Statistical analysis}

The statistical significance of the difference between the control and experimental data was analyzed using ANOVA followed by Fisher's PLSD test. A $p$ value $<0.05$ was accepted as statistically significant.

\section{Results}

Influence of TBH on MMP-2, MMP-9, TIMP-I, and TIMP-2 production from LFs

The first set of experiments was undertaken to examine the influence of TBH on MMPs production from LFs in response to TNF- $\alpha$ stimulation. LFs $\left(5 \times 10^{5}\right.$ cells $\left./ \mathrm{ml}\right)$ was stimulated with $25.0 \mathrm{ng} / \mathrm{ml} \mathrm{TNF}-\alpha$ in the presence of $0,5,15,20,25$, or $50 \mathrm{pg} / \mathrm{ml} \mathrm{TBH}$ for $24 \mathrm{~h}$. MMPs levels in culture supernatants were assayed by ELISA. As shown in Figure 1, TBH suppressed MMP-2 production from LFs, which is enhanced by TNF- $\alpha$ stimulation. The minimum concentration of the agent, which caused significant suppression of MMP-2 production

Table I Primer sequences used for real-time polymerase chain reaction

\begin{tabular}{lll}
\hline Primer sequences & Position & Product size, bp \\
\hline MMP-2 & $1740-1764$ & 440 \\
Sense 5'-AGATCTTCTTCTTCAAGGACCGGTT-3' & $1964-1943$ & \\
Antisense 5'-GGCTGGTCAGTGGCTTGGGGTA-3' & \\
MMP-9 & $1554-1573$ \\
Sense 5'-TGGACGATGCCTGCAACGTG-3' & $2008-1986$ \\
Antisense 5'-GTCGTGCGTGTCCAAAGGCA-3' & \\
TIMP-I & $150-173$ \\
Sense 5'-CACCCACAGACGGCCTTCTGCAAT-3' & $494-474$ \\
Antisense 5'-AGTGTAGGTCTTGGTGAAGCC-3' & \\
TIMP-2 & $602-625$ \\
Sense 5'-CTCGCTGGACGTTGGAGGAAAGAA-3' & 345 \\
Antisense 5'-AGCCCATCTGGTACCTGTGGTTCA-3' & $756-733$ \\
$\beta$-actin & \\
Sense 5'-ACCCACACTGTGCCCATCTA-3' & $551-570$ \\
Antisense 5'-CGGAACCGCTCATTGCC-3' & $733-717$ \\
\hline
\end{tabular}




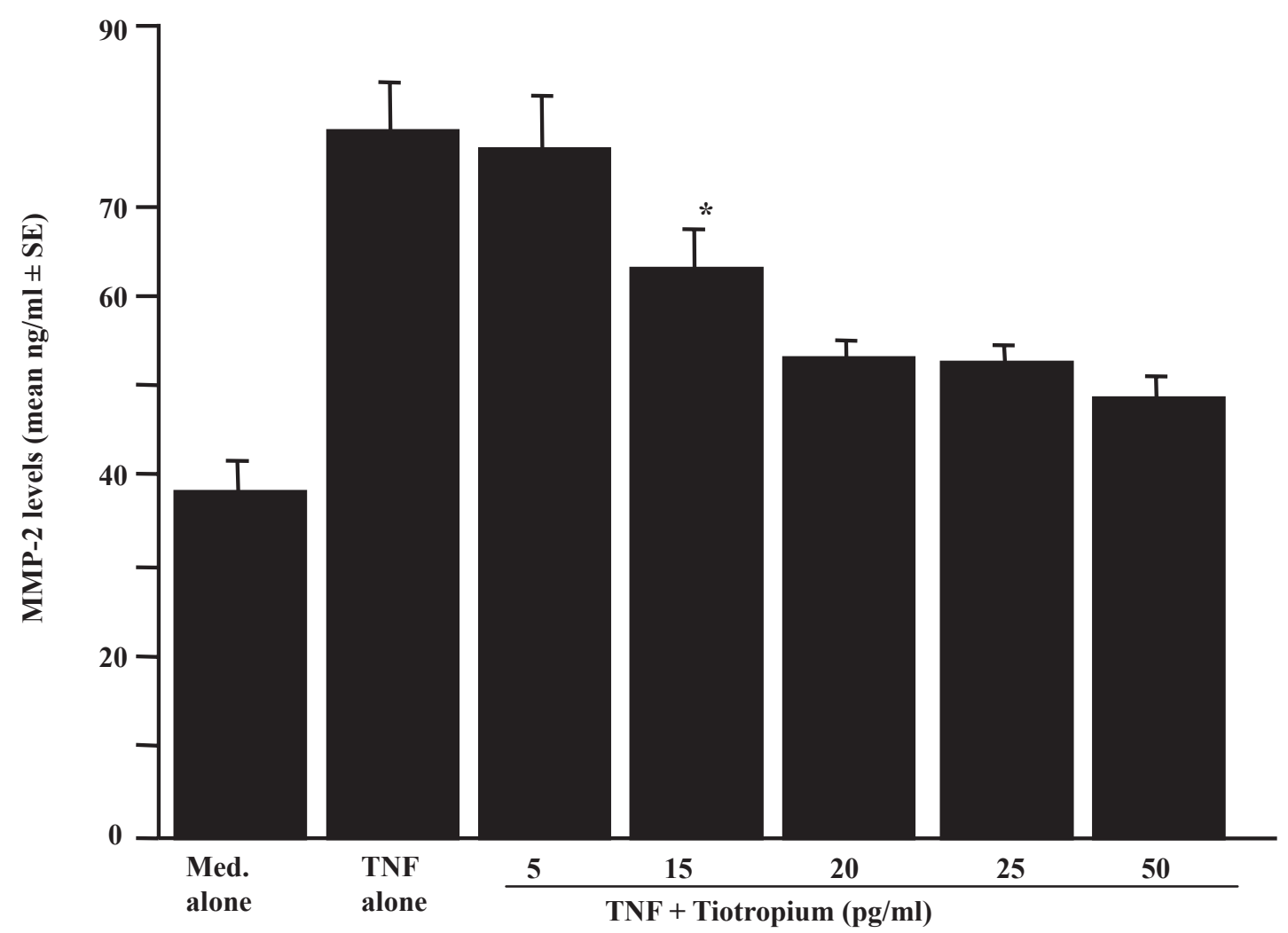

Figure I Influence of tiotropium on metalloproteinase (MMP)-2 production from lung fibroblasts induced by tumor necrosis factor (TNF)- $\alpha$ stimulation. Cells $\left(5 \times 10^{5}\right.$ cells/ml) were stimulated with $25.0 \mathrm{ng} / \mathrm{mlTNF}-\alpha$ in the presence of various concentrations of tiotropium for $24 \mathrm{~h}$. MMP- 2 levels in culture supernatants were examined by ELISA. Data are expressed as the mean $\mathrm{ng} / \mathrm{ml}+\mathrm{SE}$ of five different subjects.

Notes: *significant $(\mathrm{P}<0.05)$ as compared with TNF alone.

was $15 \mathrm{pg} / \mathrm{ml}$. On the other hand, TNF- $\alpha$ stimulation could not induce MMP-9 production from LF; culture supernatants contained undetectable levels $(<0.6 \mathrm{ng} / \mathrm{ml})$ of MMP-9 by ELISA (data not shown). We next examined the influence of TBH on the production of both TIMP-1 and TIMP-2 from LFs in response to TNF- $\alpha$ stimulation. As shown in Figures $2 \mathrm{a}$ and $\mathrm{b}$, TBH could not suppress the ability of LFs to produce TIMP-1 and TIMP-2 from LFs, even when $50 \mathrm{pg} / \mathrm{ml}$ of the agent was added to cell cultures.

\section{Influence of TBH on MMP and TIMP mRNA expression in LFs}

The second set of experiments was undertaken to examine the influence of TBH on mRNA expression for MMP-2, TIMP-1, and TIMP- 2 in LFs. LFs $\left(5 \times 10^{5}\right.$ cells $\left./ \mathrm{ml}\right)$ were stimulated with $25.0 \mathrm{ng} / \mathrm{ml} \mathrm{TNF}-\alpha$ in the presence of $0,5,15,20$, or $25 \mathrm{pg} / \mathrm{ml}$ TBH for $4 \mathrm{~h}$. Levels of mRNA expression were evaluated by real-time PCR. Addition of TBH at more than $15 \mathrm{pg} / \mathrm{ml}$ into cell cultures signif icantly suppressed MMP- 2 mRNA expression in LFs (Figure 3). However, TBH could not reduce levels of TIMP mRNA expression in LFs (Figures $4 a$ and $b$ ).

\section{Influence of TBH on transcription factor activation in LFs}

The third set of experiments was designed to examine the influence of TBH on transcription factor, NF- $\mathrm{KB}$ and AP-1, activation in LFs. LFs $\left(5 \times 10^{5}\right.$ cells $\left./ \mathrm{ml}\right)$ were stimulated with $25.0 \mathrm{ng} / \mathrm{ml}$ TNF- $\alpha$ in the presence of $0,5,15,20,25$, or $50 \mathrm{pg} / \mathrm{ml} \mathrm{TBH}$ for $4 \mathrm{~h}$. The nuclear extract was prepared, and NF- $\mathrm{\kappa B}$ activity was assessed by measuring $\mathrm{p} 50$ and $\mathrm{p} 65$ activities by ELISA. As shown in Figure 5, addition of TBH at more than $15 \mathrm{pg} / \mathrm{ml}$ caused significant suppression of $\mathrm{p} 50$ and p65 activation in LF, which was induced by TNF- $\alpha$ stimulation. On the other hand, TBH could not suppress TNF- $\alpha$ stimulated AP-1 activation, as assessed by both Fra- 2 and Jun B activities (Figure 6), even when $50.0 \mathrm{ng} / \mathrm{ml}$ of the agent was added to cell cultures.

\section{Discussion}

The present results clearly demonstrated that TBH at more than $15 \mathrm{pg} / \mathrm{ml}$ could suppress the production of MMP-2 from LFs with virtually no effect on the production of TIMP-1 and TIMP-2. In addition, this inhibitory action of TBH on 

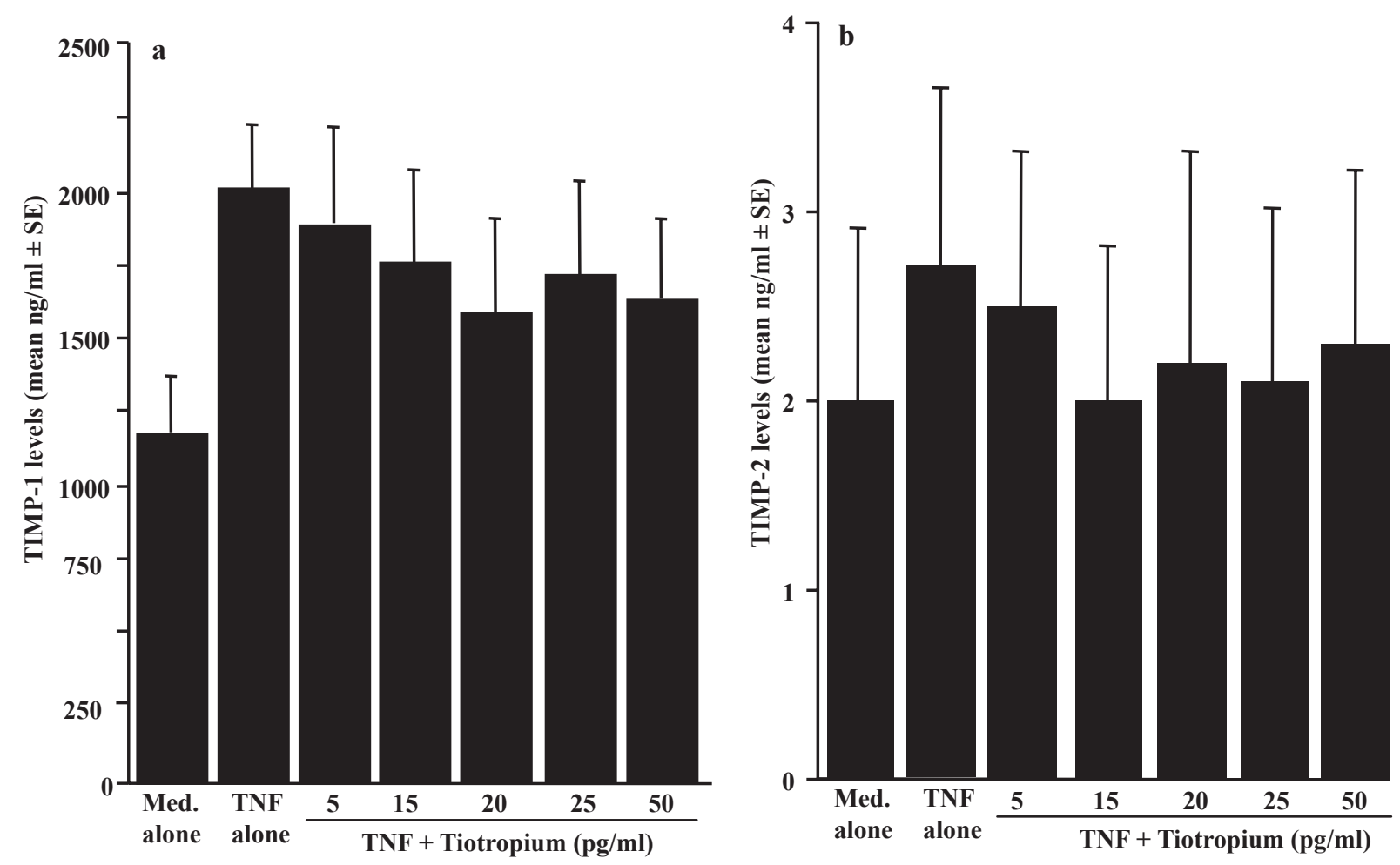

Figure 2 Influence of tiotropium on the production of tissue inhibitor of metalloproteinase (TIMP)-I (a) and TIMP-2 (b) from lung fibroblasts in response to tumor necrosis factor (TNF)- $\alpha$ stimulation. Cells $\left(5 \times 10^{5}\right.$ cells $\left./ \mathrm{ml}\right)$ were stimulated with $25.0 \mathrm{ng} / \mathrm{ml} \mathrm{TNF}-\alpha$ in the presence of various concentrations of tiotropium for $24 \mathrm{~h}$. TIMP-I and TIMP-2 levels in culture supernatants were examined by ELISA. Data are expressed as the mean $\mathrm{ng} / \mathrm{ml}+\mathrm{SE}$ of five different subjects.

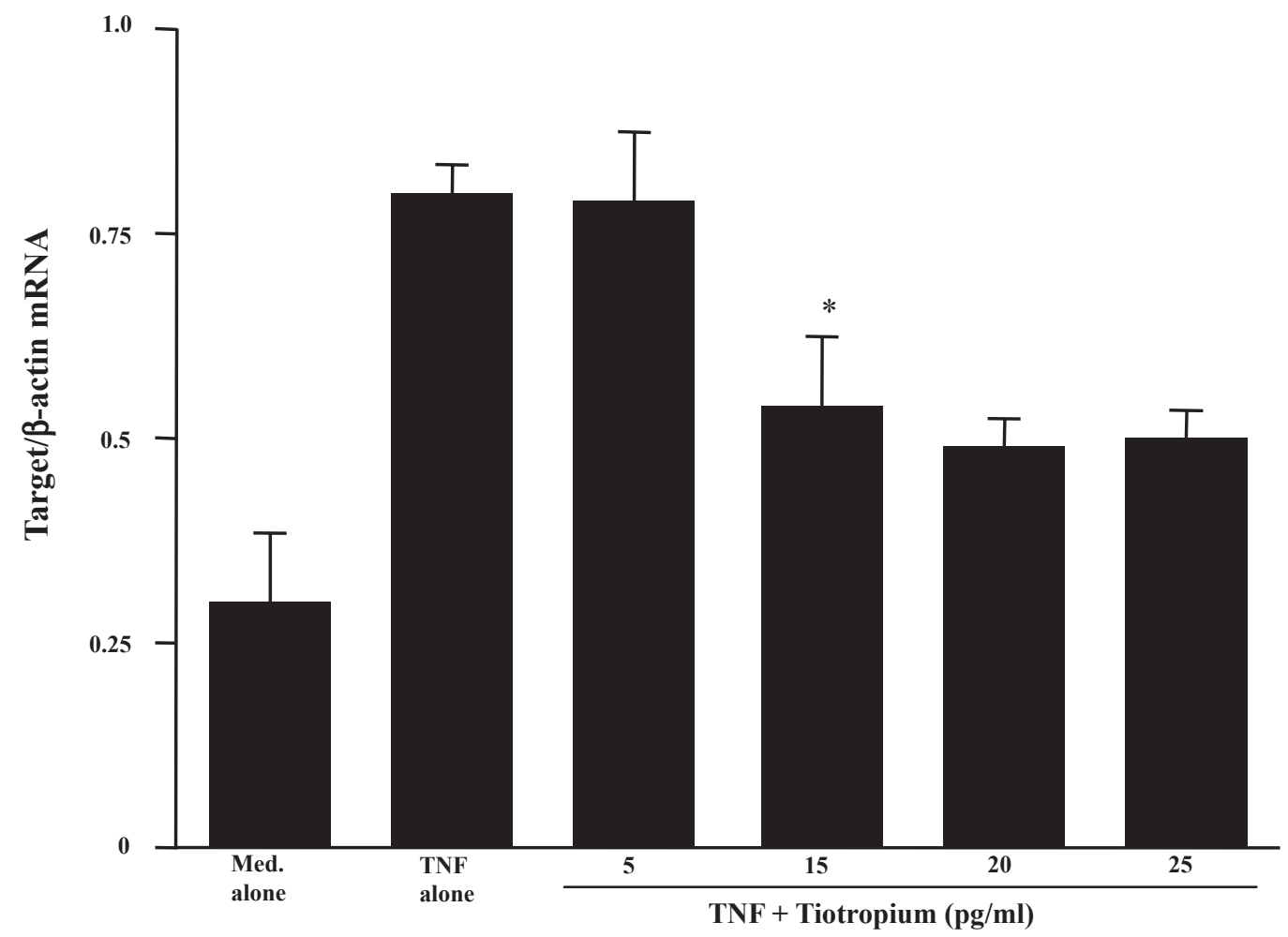

Figure 3 Influence of tiotropuim on matrix metalloproteinase (MMP)- 2 mRNA expression in lung fibroblasts after tumor necrosis factor (TNF)- $\alpha$ stimulation. Cells $\left(5 \times 10^{5}\right.$ cells $/ \mathrm{ml}$ ) were stimulated with $25.0 \mathrm{ng} / \mathrm{ml} \mathrm{TNF}-\alpha$ in the presence of various concentrations of tiotropium for $4 \mathrm{~h}$. mRNA expression was examined by real-time RT-PCR. Data are expressed as the mean ratio $+\mathrm{SE}$ of five different subjects. Notes: *significant $(\mathrm{P}<0.05)$ as compared with TNF alone. 

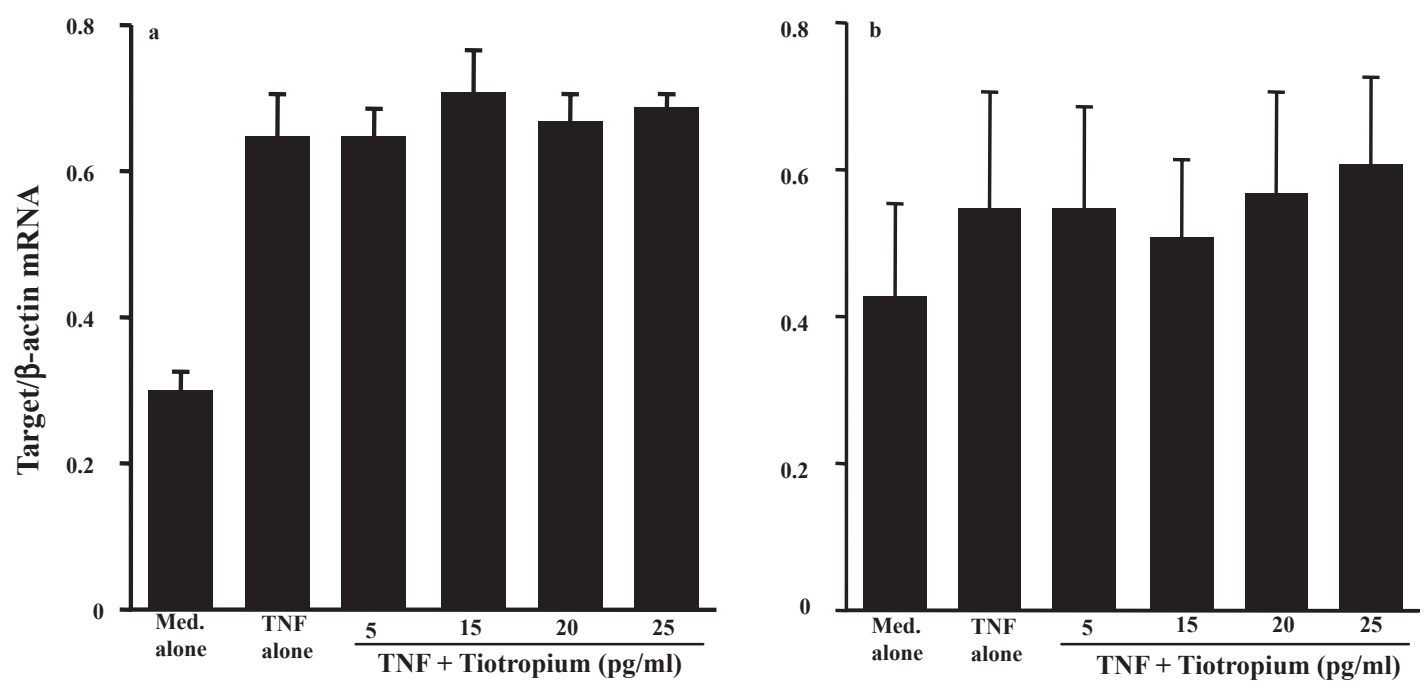

Figure 4 Influence of tiotropium on mRNA expression for tissue inhibitor of metalloproteinases (TIMP)-I (a) and TIMP-2 (b) in lung fibroblasts in response to tumor necrosis factor (TNF)- $\alpha$ stimulation. Cells $\left(5 \times 10^{5}\right.$ cells $\left./ \mathrm{ml}\right)$ were stimulated with $25.0 \mathrm{ng} / \mathrm{mlTNF}-\alpha$ in the presence of various concentrations of tiotropium for $4 \mathrm{~h}$. $\mathrm{mRNA}$ expression was examined by real-time RT-PCR. Data are expressed as the mean ratio + SE of five different subjects.

MMP production is due, in part, to its suppressive effect on MMP mRNA expression through the inhibition of transcription factor NF- $\kappa B$ activation by TNF- $\alpha$ stimulation. After oral inhalation of $\mathrm{TBH}$, plasma drug levels was gradually increased, plateued at $16 \mathrm{ng} / \mathrm{ml}$ when COPD patient was treated with $18.0 \mu \mathrm{g}$ TBH for 2-3 weeks (Keam et al 2004),

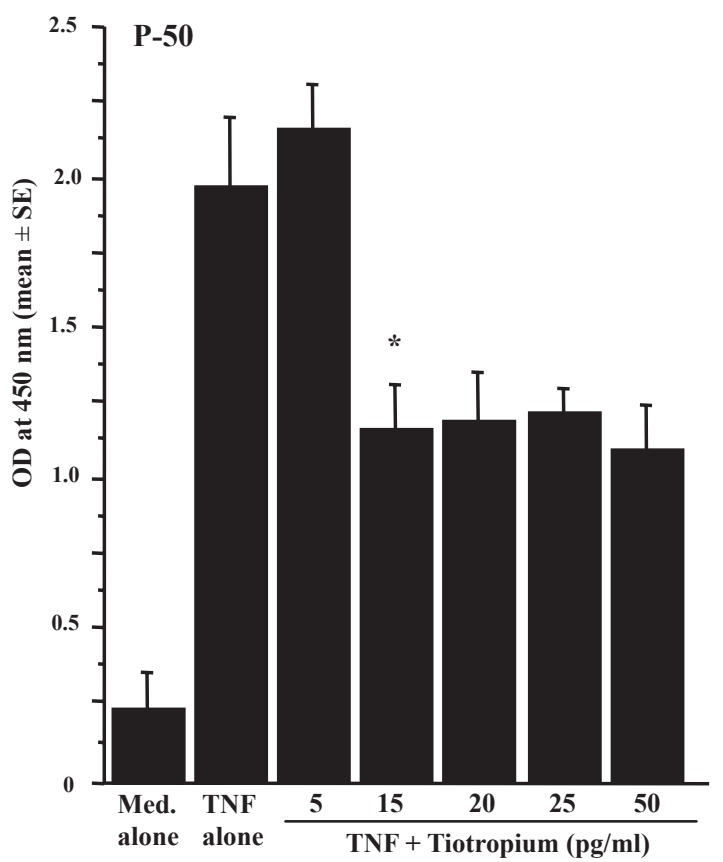

suggesting that suppression of MMP-2 production may be occurred in both airways and peripheral lung tissues of TBHtreated COPD patients.

COPD is a chronic lung disease, which is mainly induced by inhalation of cigarette smoke, resulting in irreversible airway limitation. A common feature of the disease

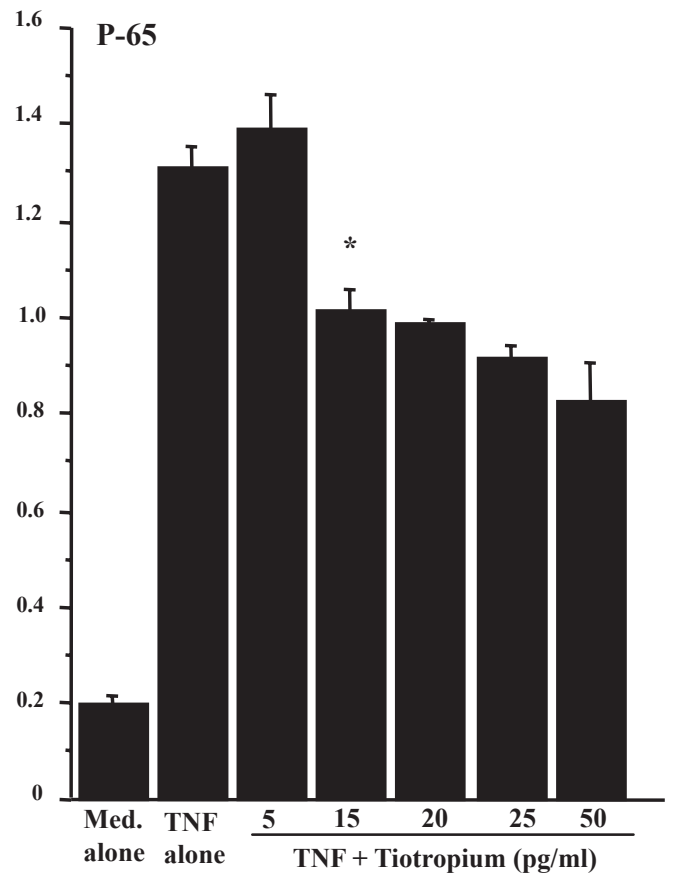

Figure 5 Influence of tiotropium on nuclear factor (NF)- $\kappa B$ activation in lung fibroblasts induced by tumor necrosis factor (TNF)- $\alpha$ stimulation. Cells $\left(5 \times 10^{5}\right.$ cells $\left./ \mathrm{ml}\right)$ were stimulated with $25.0 \mathrm{ng} / \mathrm{mITNF}-\alpha$ in the presence of various concentrations of tiotropium for $4 \mathrm{~h}$. NF- $\mathrm{kB}$, p- 50 and $\mathrm{p}-65$, activities were assayed by ELISA. Data are expressed as the mean optical density (OD) at $450 \mathrm{~nm}+\mathrm{SE}$ of five different subjects.

Notes: *significant $(\mathrm{P}<0.05)$ as compared with TNF alone. 

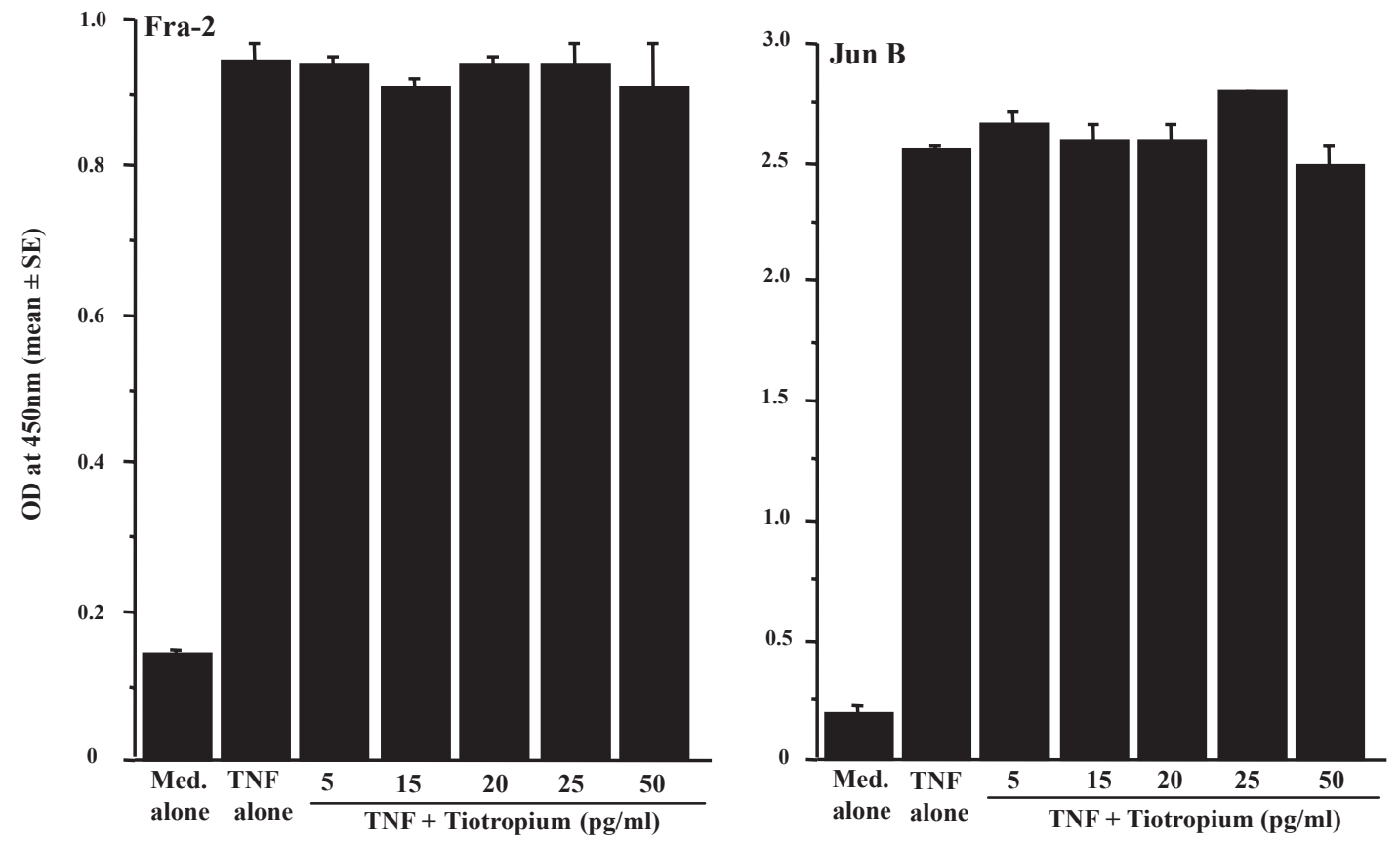

Figure 6 Influence of tiotropium on activator protein (AP)-I activation in lung fibroblasts induced by tumor necrosis factor (TNF)- $\alpha$ stimulation. Cells $\left(5 \times 10^{5}\right.$ cells $\left./ \mathrm{ml}\right)$ were stimulated with $25.0 \mathrm{ng} / \mathrm{mlTNF}-\alpha$ in the presence of various concentrations of tiotropium for $4 \mathrm{~h}$. AP-I, Fra 2 and Jun B, activities were assayed by ELISA. Data are expressed as the mean optical density (OD) at $450 \mathrm{~nm}+\mathrm{SE}$ of five different subjects.

is the chronic inflammation with intense infiltration of inflammatory cells, especially neutrophils, macrophages and T cells in the airways and lungs (Hamid et al 2004; Hogg et al 2004; Jeffery 2004). Histological observation also revealed structural abnormalities, including thickening of the basement membrane, structural fibrosis and mucous gland hyperplasia (Hamid et al 2004; Hogg et al 2004; Jeffery 2004). These cellular events are now called tissue remodeling, and are involved in an extensive alteration of ECM, which is essential for supporting normal lung functions (Elkington et al 2006). It is also reported that, in some cases of COPD, this tissue remodeling causes destruction of healthy lung tissue, leading to emphysema (Demedts et al 2005). Consideration of the biochemistry of the lung matrix predicts that the MMP family of enzymes is likely to be involved in this pathology (Demedts et al 2005; Elkington et al 2005; Lagente et al 2005; Babusyte et al 2007; Lowrey et al 2008). MMPs are a family of $\mathrm{Ca}^{2+}$-activated, $\mathrm{Zn}^{2+}$-dependent proteases that can degrade various components of the ECM and basement membrane. MMPs are classified on the basis of substrate specificity into collagens (MMP-1, and -8), gelatinase (MMP-2 and -9), and elastases (MMP-7 and -12), among others (Elkington et al 2005; Lagente et al 2005). In an analysis of MMPs expression in COPD, MMP-1, $-2,-8$, and -9 were found to be upregulated (Segura-Valdez et al 2000; Baraldo et al 2007; Lowrey et al 2008). Immunohistochemical analysis has also demonstrated increased MMP-14 expression in emphysematous lung tissues (Ohnishi et al 1998). Furthermore, the studies combining ELISA, immunocytochemistry and a collagen degradation assay revealed the increased levels of MMP-1 and -12 in patients with COPD (Imai et al 2001). From these reports, it is possible that the attenuating effect of TBH on MMP-2 production from LFs induced by TNF- $\alpha$ stimulation may be additional beneficial therapeutic effects not directly relating to its bronchodilatory effects. The extracellular activity of MMPs is regulated by TIMPs that form an 1:1 complex with MMPs (Nagase 1997). The present results clearly showed that TBH could not inhibit the TIMP-1 and -2 production from LFs after TNF- $\alpha$ stimulation, suggesting that MMP-2 secreted in small amounts from LFs during TBH treatment are inactivated by TIMPs, and resulting in modification of clinical symptoms derived from ECM remodeling and accumulation of inflammatory cells in COPD.

Although the present results clearly showed the suppressive effect of TBH on MMP production from LFs induced by TNF- $\alpha$ stimulation, the mechanisms by which TBH could suppress MMP production are not well understood. TNF- $\alpha$ is a multifunctional cytokine that plays a role in inflammation, immunity and a variety of diseases. It is also reported that binding of TNF- $\alpha$ to the type- 1 TNF receptor causes an increase in intracellular $\mathrm{Ca}^{2+}$ concentration through calcium influx (Lazaar et al 1998), and results in activation of 
$\mathrm{NF}-\kappa \mathrm{B}$, which are essential transcription factors for MMP-2 production (Wasylyk et al 1991; Sato et al 1993; Okamoto et al 1994). Solifenacin succinate, a newly developed muscarinic receptor antagonist, could inhibit carbachol-induced intracellular $\mathrm{Ca}^{2+}$ mobilization in guinea pig smooth muscle cells and murine submandibular gland cells in vitro (Ikeda et al 2002). Soliferan succinate and the other antimuscarinic drugs, such as darifenacin and oxybutynin chloride, which have higher affinity for muscarinic $\mathrm{M}_{3}$ receptor, are also reported to inhibit increase in intracellular $\mathrm{Ca}^{2+}$ levels in rat salivary gland cells induced by carbachol stimulation (Ohtake et al 2004). Furthermore, otilonium bromide, a muscarinic receptor antagonist, could inhibit the increase in intracellular calcium levels in cells from rat colon by blocking L-type calcium channel (Martin et al 2004). Judging from these reports, it is possible that addition of TBH into LFs cultures caused inhibition of $\mathrm{Ca}^{2+}$ mobilization induced by TNF- $\alpha$ stimulation, and resulted in suppression of MMP-2 production through the inhibition of transcription factor, especially $N F-\kappa B$, activation. On the other hand, TNF- $\alpha$-induced gene transcription in many cell types is mediated by a number of signal transduction pathways, including those involving extracellular signal-regulated kinase (ERK), mitogen activated protein-kinase (MAPK), Jun N-terminal kinase (JUN), NF- $\kappa \mathrm{B}$ and AP-1 (Turner et al 2005). In these pathways, activation of ERK and MAPK is essential for TNF- $\alpha$-mediated MMP gene expression in fibroblasts after TNF- $\alpha$ stimulation (Barchowsky et al 2000; Domeij et al 2002; Nee et al 2007). From these reports and the present results showing that the inhibitory action of TBH on the NF- $\kappa B$ activation may suggest that TBH inhibits ERK and MPK activation and results in suppression of MMP production in LFs after TNF- $\alpha$ stimulation. This speculation may be supported, in part, by the observation that muscarinic receptor antagonists could prevent inflammatory protein production induced by acetylcholine stimulation through the inhibition of ERK-NF- $\kappa$ B activation (Profita et al 2008). In addition to the above mentioned signal transduction pathways, TNF- $\alpha$ stimulation causes RhoA/Rho kinase activation, which is responsible for the production of MMP-9 and transmembrane metalloproteinase, MT1-MMP (Meriane et al 2006), through enhancement of JNK activation in endothelial cells after TNF- $\alpha$ stimulation (Hunter et al 2006; Mong et al 2008). It is also reported that AP-1 up-regulation induced by TNF- $\alpha$ simulation requires JNK activation (Ventura et al 2003; Mong et al 2008). From these reports, there is a possibility that $\mathrm{TBH}$ may directly inhibit up-regulation of RhoA/Rho kinase induced by TNF- $\alpha$ stimulation in LFs and results in suppression of MMP-2 production, since TBH could not suppress AP-1 activation by TNF- $\alpha$ stimulation in LFs. Anyway, further experiments are required to clarify the mechanisms by which TBH inhibits MMP-2 production from LFs in response to TNF- $\alpha$ stimulation.

Different from MMPs, PEA3, a protooncogene-related transcriptional factor, is involved in the regulation of TIMP transcription (De Clerk et al 1994; Sato et al 2002). From these reports, the present results may be interpreted that $\mathrm{TBH}$ could not inhibit PEA3 activation by TNF- $\alpha$ stimulation and results in negative suppressive effects on TIMP production from LFs.

MMPs are produced by numerous cell types, including fibroblast, macrophages and neutrophils in response to inflammatory stimulation, and mediated transmigration of the inflammatory cells through the basement membrane to propagate inflammation (Hoshino et al 1998; Herouy et al 2001). MMPs are also responsible for microvascular permeability leading to oedema and enhanced inflammatory cell migration (Hoshino et al 1998; Herouy et al 2001), suggesting that administration of $\mathrm{TBH}$ into COPD patients attenuates inflammatory responses in the airways and lungs, and may result in favorable modification of clinical status of COPD, including exacerbation frequency. However, a recent report showed that $\mathrm{TBH}$ therapy for one year could not reduce the levels of inflammatory makers, such as IL-6, IL-8, and myeloperoxidase in sputum from COPD patient as compared with placebo-treated patients (Powrie et al 2007). The reasons for this discrepancy are not clear at present. TBH is well accepted to be able to potentially inhibit cholinergic stimulation of mucus-secreting goblet cells in the airways to cause reduction in total volume of sputum, resulting in increase in protein levels in sputum. This may be responsible for negative suppressive effect of $\mathrm{TBH}$ on inflammatory marker levels in sputum.

Finally, this is the first report showing that TBH exerts suppressive effect on MMP production from lung fibroblasts induced by an inflammatory stimulation, and this suppressive activity of TBH may be additional beneficial effects not directly relating to its bronchodilatory effects in COPD patients.

\section{Disclosure}

The authors report no conflicts of interest in this work.

\section{References}

Babusyte A, Stravinskaite K, Jeroch J, et al. 2007. Patterns of airway inflammation and MMP-12 expression in smokers and ex-smokers with COPD. Respir Res, 8:81-9. 
Baraldo S, Bazzan E, Zanin ME, et al. 2007. Matrix metalloproteinase-2 protein in lung periphery is related to COPD progression. Chest, 132:1733-40.

Barchowsky A, Frleta D, Vincenti MP. 2000. Intergration of the NF-kappaB and mitogen-activated protein kinase/AP-1 pathway at the collagenase-1 promotor: divergence of IL-1 and TNF-dependent signal transduction in rabbit primary synovial fibroblasts. Cytokine, 12:1469-79.

Casaburi R, Mahler DA, Jones PW, et al. 2002. A long-term evaluation of once-daily inhaled tiotropium in chronic obstructive pulmonary disease. Eur Respir J, 19:205-6.

Cataldo D, Munaut C, Noel A, et al. 2000. MMP-2- and MMP-9-linked gelatinolytic activity in the sputum from patients with asthma and chronic obstructive pulmonary disease. Int Arch Allergy Immunol, 123:259-67.

Demedts IK, Brusselle GG, Bracke KR, et al. 2005. Matrix metalloproteinases in asthma and COPD. Current Opinion Pharmacol, 5:257-63.

De Clark YA, Darville MI, Eeckhout Y, et al. 1994. Characterization of the promotor of the gene encoding human tissue inhibitor of metalloproteinase-2 (TIMP-2). Gene, 139:185-91.

Domaij H, Yucel-Lindberg T, Modeer T. 2002. Signal pathways involved in the production of MMP-1 and MMP-3 in human gingival fibroblasts. Eur J Oral Sci, 110:302-6.

Disse B. 2001. Antimuscarinic treatment for lung diseases from research to clinical practice. Life Sci, 68:2557-64.

Dusser D, Bravo ML, Iacono P. 2006. The effect of tiotropium on exacerbations and airflow in patients with COPD. Eur Respir J, 27:547-55.

Elkington PTG, Friedland JS. Matrix metalloproteinases in destructive pulmonary pathology. Thorax, 61:259-66.

Gosens R, Bos IS, Zaagsma J, et al. 2005. Protective effects of tiotropium bromide in the progression of airway smooth muscle remodeling. Am J Respir Crit Care Med, 171:1096-102.

Hamid Q, Cosio M, Lim S. 2004. Inflammation and remodeling in chronic obstructive pulmonary diseases. J Allergy Clin Immunol, 114:1479-81.

Herouy Y, Mellos P, Bandemir E, et al. 2001. Inflammation in stasis dermatitis upregulates MMP-1, MMP-2, and MMP-13 expression. J Dermatol Sci, 25:198-205.

Hogg JC, Chu F, Utokaparch S, et al. 2004. The nature of small-airway obstruction in chronic obstructive pulmonary disease. $N$ Engl J Med, 350:2645-53.

Hoshino M, Nakamura Y, Sim JJ, et al. 1998. Bronchial subepithelial fibrosis and expression of matrix metalloproteinase- 9 in asthmatic airway inflammation. J Allergy Clin Immunol, 102:783-8.

Hunter I, Nixon GF. 2006. Spatial compartmentalization of tumor necrosis factor (TNF) receptor 1-dependent signaling pathways in human airway smooth muscle cells: lipid rafts are essential for TNF- $\alpha$-mediated activation of RhoA but dispensable for the activation of the NF- $\mathrm{KB}$ and MAPK pathways. $J$ Biol Chem, 281:34705-15.

Ikeda K, Kobayashi S, Suzuki M, et al. 2002. M3 receptor antagonism by the novel antimuscarinic agent solifenacin in the urinary bladder and salivary gland. Naunyn Schmiedebergs Arch Pharmacol, 366:97-103.

Imai K, Dalal SS, Chen ES, et al. 2001. Human collagenase (matrix metalloproteinase-1) expression in the lungs of patients with emphysema. Am J Respir Crit Care Med, 163:786-91.

Jeffery PK. 2004. Remodeling and inflammation of bronchi in asthma and chronic obstructive pulmonary disease. Proc Am Thorac Soc, $1: 176-83$.

Kang MJ, Oh YM, Lee JC, et al. 2003. Lung matrix metalloproteinase-9 correlates with cigarette smoking and obstruction of airflow. J Korean Med Sci, 18:821-7.

Keam SJ, Keating GM. 2004. Tiotropium bromide. A review of its use as maintenance therapy in patients with COPD. Treat Respir Med, 3:247-68.

Lagente V, Manoury B, Nenan S, et al. 2005. Role of matrix metalloproteinases in the development of airway inflammation and remodeling. Braz J Med Biol Re, 38:1521-30.

Lazaar AL, Amrani Y, Hsu J, et al. 1998. CD40-mediated signal transduction in human airway amooth muscle. J Immunol, 161:3120-7.
Lowrey G, Henderson N, Blakey JD, et al. 2008. MMP-9 protein level does not reflect overall MMP activity in the airways of patients with COPD. Respir Med, 102:845-51.

Martin MT, Hove-Madsen L, Jimenz M. 2004. Otilonium bromide inhibits muscle contractions via L-type calcium channels in the rat colon. Neurogastroenterol Motil, 16:175-83.

Meriane M, Duhamel S, Lejeune L, et al. 2006. Cooperation of matrix metalloproteinases with the RhoA/Rho kinase and mitogen-activated protein kinase: Kinase-1/extracellular signal-regulated kinase signaling pathways is required for the shingosine-1-phosphate-induced mobilization of marrow-derived stroma cells. Stem Cells, 24:2557-65.

Murphy G, Docherty AJ. 1992. The matrix metalloproteinases and their inhibitors. Am J Respir Cell Mol Biol, 7:120-5.

Mong PY, Petrulio C, Kaufman HL, et al. 2008. Activation of Rho Kinase by TNF- $\alpha$ is required for JNK activation in human pulmonary microvascular endothelial cells. J Immunol, 180:550-8.

Nagase H. 1997. Activation mechanisms of matrix metalloproteinase. Biol Chem, 378:151-60.

Nee L, Tuite N, Ryan MP, et al. 2007. TNF-alpha and IL-1 beta-mediated regulation of MMP-9 and TIMP-1 in human glomelular mesangial cells. Nephron Exp Nephrol, 107:73-86.

Ohnishi K, Takagi M, Kurokawa Y, et al. 1998. Matrix-metalloproteinasemediated extracellular matrix protein degradation in human pulmonary emphysema. Lab Invest, 78:1077-87.

Ohtake A, Ukai M, Hatanaka T, et al. 2004. In vitro and in vivo tissue selectivity profile of solifenacin succinate (YM905) for urinary bladder over salivary gland in rats. Eur J Pharmacol, 492:243-50.

Okamoto SI, Mukaida N, Yasumoto K, et al. 1994. The interleukin-8, AP-1 and kB-like sites are genetic end targets of FK-506-sensitive pathway accompanied by calcium mobilization. $J$ Biol Chem, 269:8582-9.

Powrie DJ, Wilkinson TMA, Donaldson GC, et al. 2007. Effect of tiotropium on sputum and serum inflammatory markers and exacerbation in COPD. Eur Res J, 30:472-8.

Profita M, Bonanno A, Siena L, et al. 2008. Acetylcholine mediates the release of IL-9 in human bronchial epithelial cells by a NFKB/ERKdependent mechanism. Eur J Pahrmacol, 582:145-53.

Rodrigo GJ, Nannini LJ. 2007. Tiotropium for the treatment of stable chronic obstructive pulmonary diseases: a systemic review with meta-analysis. Pulm Pharmacol Ther, 20:495-502.

Sato H, Seiki M. 1993. Regulation of $92 \mathrm{kDa}$ type IV collagenase gene expression which is associated with invasiveness of tumor cells. Oncogene, 8:395-405.

Sato T, Koike L, Miyata Y, et al. 2002. Inhibition of activator protein-1 binding activity and phosphatidylinositol 3-kinase pathway by a polymethoxy flavonoid, results in augmentation of tissue inhibitor of mettaloproteinase-2 production and suppression of production of matrix metalloproteinases-2 and -9 in human fibrosarcoma HT-1080 cells. Cancer Res, 62:1025-9.

Segura-Valdez L, Pardo A, Gaxiola M, et al. 2000. Upregulation of elatinases $\mathrm{A}$ and $\mathrm{B}$, collagenases 1 and 2, and increased parenchymal cell death in COPD. Chest, 117:684-94.

Suzaki H, Asano K, Yu M, et al. 2003. Influence of roxithromycin on inflammatory cytokine production from nasal polyp fibroblasts in vitro. Acta Otolaryngol, 123:637-42.

Turner NA, O'Regan DJ, Ball SG, et al. 2005. Simvastatin inhibits MMP-9 secretion from human saphenous vein smooth muscle cells by inhibiting the Rho/ROCK pathway and reducing MMP-9 mRNA levels. FASB J, 19:804-6.

Vincken W, Van Noord JA, Greefhorst AP, et al. 2002. Improved health outcomes in patients with COPD during 1yr's treatment with tiotropium. Eur Respir J, 19:217-24.

Ventura JJ, Kennedy NJ, Lamb JA, et al. 2003. c-Jun NH2-terminal kinase is essential for the regulation of AP-1 by tumor necrosis factor. Med. Cell Biol, 23:2871-82.

Wasylyk C, Gutman A, Nicholson R, et al. 1991. The c-Ets oncoprotein activates the stromelysin prompter through the same elements as several non-nuclear oncoprotein. EMBO J, 10:1127-34. 
